\title{
Hydropower projects and environmental licensing process: how different countries manages the problem
}

Projetos hidrelétricos e processo de licenciamento ambiental: como diferentes países gerenciam o problema

Proyectos hidroeléctricos y proceso de licencia ambiental: cómo diferentes países manejan el problema

Marco Aurélio dos Santos
ORCID: https://orcid.org/0000-0002-2422-3765
Energy Planning Program, Brazil
Federal University of Rio de Janeiro, Brazil
E-mail: aurelio@ppe.ufr.br
André Lima Andrade
ORCID: https://orcid.org/0000-0003-4854-4667
Environmental Analyst at IBAMA, Brazil
E-mail: andreandrade02@hotmail.com
Brazilian Institute for the Environment and Renewale Narual Reurces Brazil
Orleno Marques da Silva Junior
ORCID: https://orcid.org/0000-0003-4854-4667
IEPA researcher, Brazil
Enstitute of Scientific and Technological Research of the State of Amapá, Brazil
E-mail: orlenomarques@yahoo.com.br
Gloria Maria dos Santos Marins
ORCID: https://orcid.org/0000-0001-9066-449X
Energy Planning Program, Brazil
Federal University of Rio de Janeiro, Brazil
E-mail: gloriamarins@ppe.ufrj.br
Paulo Eduardo Aragon Marçal Ribeiro
ORCID: https://orcid.org/0000-0001-5652-2535
Energy Planning Program, Brazil
Federal University of Rio de Janeiro, Brazil
E-mail: padu.aragon@hotmail.com
Patrícia Schumer Nunes Boité
ORCID: https://orcid.org/0000-0002-3460-9629
Energy Planning Program, Brazil
Federal University of Rio de Janeiro, Brazil
E-mail: patriciaschumer@ppe.ufrj.br
Vanessa Riccioppo de Moraes
Energy Planning Program, Brazil
ORCID: https://orcid.org/0000-0002-8486-9111
Federal University of Rio de Janeiro, Brazil
E-mail: vanessaricc@yahoo.com.br

\begin{abstract}
This research seeks to establish a comparative study among selected countries (Brazil, United States, Canada, Chile and Portugal), regarding aspects of the environmental licensing process for hydroelectric projects. The previous studies consider the Brazilian environmental licensing process to be very complex and differentiated from the other selected countries. There is also a lack of homogeneity among the countries surveyed. In general, environmental licensing is considered a "bottleneck" for the Brazilian electricity sector. With this analysis, it was intended to verify what types of procedures exist in other countries and that could be adopted by Brazil, in order to improve the environmental licensing process of hydroelectric plants. Thus, according to the experience of the countries analyzed, Brazil could improve relations with indigenous peoples and establish a maximum period for finalizing the licensing of hydroelectric plants. Comparative international experiences are important for possible adjustments in the Brazilian licensing process, however, one must not confuse the bureaucracy of the process with excessive simplification.
\end{abstract}

Keywords: Hydroelectric power; Environmental licensing; Environmental regulation. 


\begin{abstract}
Resumo
Esta pesquisa busca estabelecer um estudo comparativo entre países selecionados (Brasil, Estados Unidos, Canadá, Chile e Portugal), sobre aspectos do processo de licenciamento ambiental de empreendimentos hidrelétricos. Os estudos anteriores consideram que o processo de licenciamento ambiental brasileiro é muito complexo e diferenciado dos demais países selecionados. Há também uma falta de homogeneidade entre os países pesquisados. Em geral, as licenças ambientais são consideradas um "gargalo" para o setor elétrico brasileiro. Com essa análise, pretendeu-se verificar que tipos de procedimentos existem em outros países e que poderiam ser adotados pelo Brasil, a fim de aprimorar o processo de licenciamento ambiental de usinas hidrelétricas. Assim, de acordo com a experiência dos países analisados, o Brasil poderia melhorar as relações com os povos indígenas e estabelecer um prazo máximo para finalizar a outorga de licenças para usinas hidrelétricas. Experiências internacionais comparativas são importantes para possíveis ajustes no processo de licenciamento brasileiro, porém, a burocracia do processo não deve ser confundida com simplificação excessiva.

Palavras-chave: Energia hidrelétrica; Licenciamento ambiental; Regulação ambiental.
\end{abstract}

\title{
Resumen
}

Esta investigación busca establecer un estudio comparativo entre países seleccionados (Brasil, Estados Unidos, Canadá, Chile y Portugal), sobre aspectos del proceso de licenciamiento ambiental para proyectos hidroeléctricos. Los estudios anteriores consideran que el proceso de licenciamiento ambiental brasileño es muy complejo y diferenciado de los demás países seleccionados. También hay una falta de homogeneidad entre los países encuestados. En general, las licencias ambientales se consideran un "cuello de botella" para el sector eléctrico brasileño. Con este análisis, se pretendió verificar qué tipos de procedimientos existen en otros países y que podrían ser adoptados por Brasil, con el fin de mejorar el proceso de licenciamiento ambiental de las centrales hidroeléctricas. Así, según la experiencia de los países analizados, Brasil podría mejorar las relaciones con los pueblos indígenas y establecer un plazo máximo para finalizar la concesión de licencias de centrales hidroeléctricas. Las experiencias internacionales comparadas son importantes para posibles ajustes en el proceso de licenciamiento brasileño, sin embargo, no se debe confundir la burocracia del proceso con una simplificación excesiva.

Palabras clave: Energía hidroeléctrica; Licenciamiento ambiental; Regulación ambiental.

\section{Introduction}

Significant part of the world energy matrix is still composed of non-renewable thermal sources (coal, oil and oil products and natural gas) and are responsible for about $65 \%$ of CO2 emissions in atmosphere (IPCC, 2014).

These emissions significantly contribute to global warming and have been raising an alert about the need to introduce renewable energy sources in energy matrices around the world (Steeves, \& Ouriques, 2016; Kumar, 2020; Mercure et al., 2021). However, the integration process is complex, since each source has different impacts in terms of nature, magnitude and significance.

This is reflected in the generation of energy by hydroelectricity, because despite being considered renewable and generating benefits, it also generates negative socio-environmental impacts, such as changes in the balance of ecosystems and in the lives of traditional populations in the area (Rosenberg et al., 2000; Santos et al., 2000; Santos et al. al., 2008; IEA, 2012; Damazio et al., 2017; Silva Junior et al., 2018).

With this, in view of the strategic relevance of the hydroelectric sector, and the positive and negative impacts, the importance of the environmental licensing process and its effectiveness as a planning and decision-making tool, in the control and preventive monitoring of activities, during the construction, operation and decommissioning processes. In this process, it is important to consider the socio-natural characteristics, socio-environmental and economic factors of the countries.

Brazil is trying to modernize its environmental licensing based on international best practices such as the New General Licensing Law under discussion at the federal level, with this analysis, it was intended to verify what types of procedures exist in other countries and that could be adopted by Brazil, in order to improve the environmental licensing process for hydroelectric plants.

In this way, the present research performs a critical comparative analysis of the environmental licensing process in Brazil with the United States, Canada, Chile and Portugal, emphasizing, in turn, the particularities of each location and considering the phases of implementation, development, construction, operation and decommissioning of hydroelectric projects. 


\section{Methodology}

This work was developed by the method of bibliographic review, and consists of the analysis of environmental legislation in Brazil, Canada, Chile, the United States and Portugal, with a focus on environmental licensing.

The objective is to know how this instrument is applied in these countries, in relation to the following aspects of interest: 1) Institutions involved in the process 2) Orientation guides 3) Government database to support environmental licensing 4) Integration with planning instruments: zoning, among others 5) Types of environmental licenses 6) Environmental Impact Assessment (EIA) using an instrument equivalent to the Environmental Impact Study and its corresponding Environmental Impact Report (EIA-Rima) 7) Strategic Environmental Assessment (SEA) 8) Environmental compensation 9) Deadlines involved in the licensing process and 10) Participation by society.

To this end, the Federal Constitution, the National Environmental Policy and the main rules governing the environmental licensing process in each country were examined, focusing on the aforementioned aspects. The legal instruments were analyzed up to the level at which it was possible to issue some kind of answer to the ten demanded questions.

It is noteworthy that the searches were carried out on official government websites, whose texts are written in the language of each country, and it was necessary to access the content of these rules through translations, which sometimes brought some difficulty in interpreting the documents. legal texts. In order to facilitate the understanding of the content of this study, it was decided to present the analysis of each country standard.

The six countries analyzed are located at different latitudes, and have climates that vary from polar, temperate, subtropical, desert and tropical and together have almost 30 million $\mathrm{km}^{2}$ of land area (Figure 1).

Figure 1: World map with emphasis on the countries analyzed.

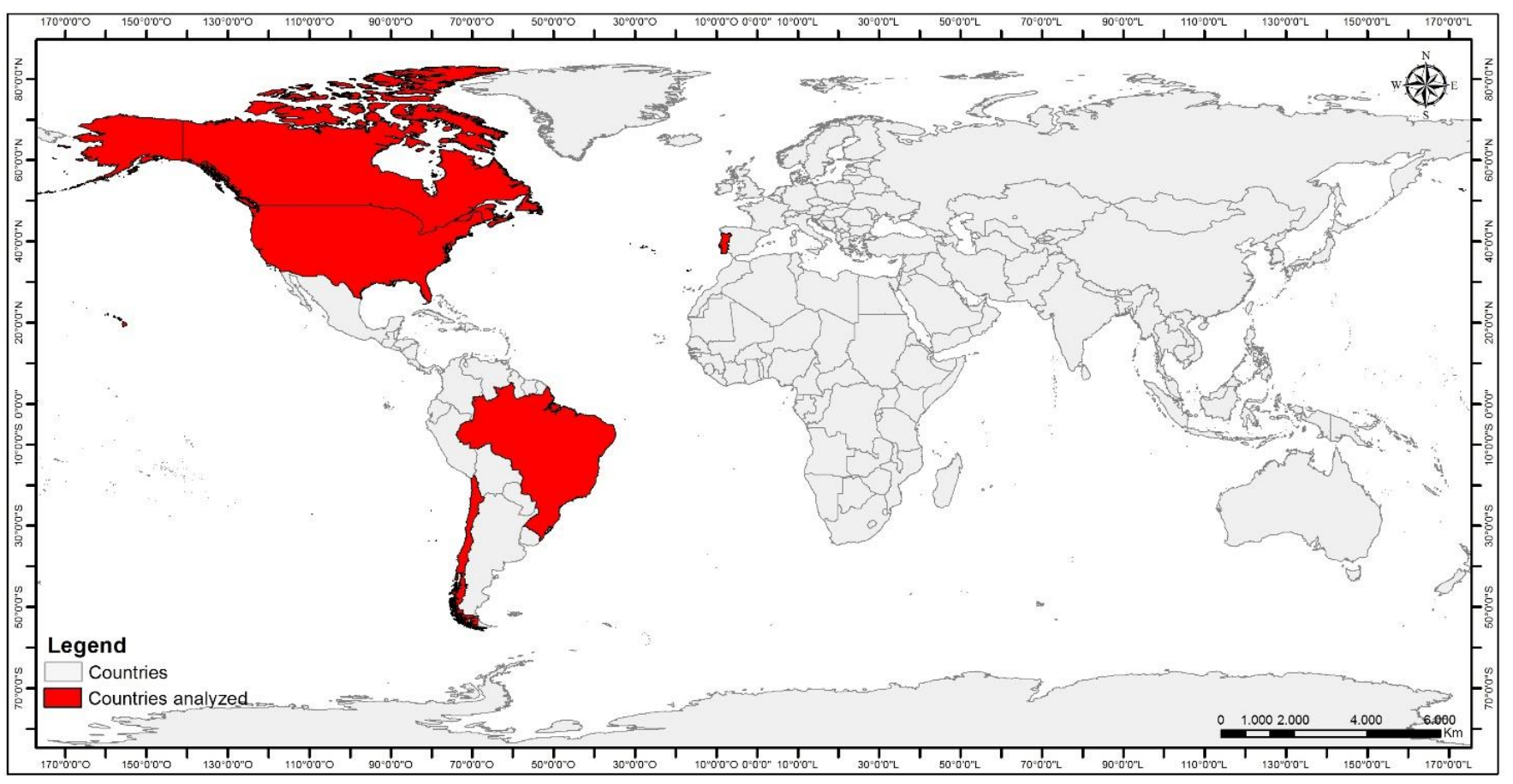

Source: Authors.

According to Natural Resources (2019), Canada have 563 hydroelectric facilities, of which 518 have a capacity of at least 1 megawatt (MW), 45 facilities less than $1 \mathrm{MW}$ and 20 plants with over 1,000 megawatts, having a total hydroelectricity capacity of 80,764 MW in 2017, and having among the largest hydroelectric installations: respectively, the Robert-Bourassa 
plant, with 5,616 MW of capacity, followed by Churchill Falls, with 5,428 MW.

In the USA, $17 \%$ of the electricity generated comes from renewable sources, of which $7 \%$ correspond to hydroelectric energy; that is, the hydroelectric plants (HPPs) are responsible for generating $41 \%$ of the renewable energy share in that country (US EIA, 2012). The installed capacity in the United States is $100 \mathrm{GW}$ (USA, 2012), of which, more than half is installed in only three states: Washington, California and Oregon.

However, it is necessary to show that the country has about 5,000 dams for electricity generation, the largest of which, Grand Coulee Dam, located in Washington, with a generation capacity of $6.8 \mathrm{GW}$ (Piagentini et al., 2014).

There is no forecast in its energy planning on the construction of new large hydroelectric projects. Rather, upgrades to the technology in the power houses of the existing dams will be made, incrementally increasing the productivity of the plants, and minimizing the occurrence of environmental impacts resulting from the construction of the same (Bermann, 2007).

In Portugal, $30 \%$ of the consumed electricity is supplied by hydroelectric plants continental and oceanic. The regions with strong potential are located in the north and center of the country, with installed capacity ranging from $3.3 \mathrm{MW}$ to $35 \mathrm{MW}$.

Chile, there is a potential of $16 \mathrm{GW}$ in hydroelectric projects, which represents about $14.9 \%$ of the country's electricity matrix. However, only $5.4 \mathrm{GW}$ are currently installed.

The hydropower has historically accounted for about $14 \%$ of primary energy production in Brazil, making it almost a hallmark of the country for having an energy matrix deriving a significant portion of energy from hydraulic power.

According to the National Energy Balance data from 2018, electricity generation was fundamentally based on hydroelectric generation, providing $65 \%$ of the total generated (BEN, 2019).

In addition, according to the National Water Agency (ANA), Brazil has, up to the current period (2020), 13,529 dams registered, of which 11,748 dams are of multiple uses (used for human supply, irrigation, industrial supply, leisure and animal drinking); 1,261 are for hydroelectric power generation; 264 for mining waste and 256 for industrial waste.

\section{Results and Discussion}

\subsection{The Environmental Licensing of Hydroelectric Power in Different Countries}

The United States does not foresee the construction of new large hydroelectric projects, therefore, most of the licensing processes underway in the USA currently contemplate renewing existing licenses (relicensing).

It is relevant to note that National Environmental Policy Act (NEPA) created the Council on Environmental Quality (CEQ) as the institution responsible for the definition of programs, rules and procedures for the Environmental Impact Assessment - EIA. This new rule including the presentation of environmental impact studies, which can be an Environmental Impact Statement (EIS), when found that the environmental impact is probably significant, or Environmental Assessment (EA), when the environmental impact is probably not significant (Piagentini et al., 2014).

In the US, several federal agencies are responsible for conducting the EIA process, including the EPA, in contrast with Brazil, where the applicant for the project is responsible for the preparation of environmental studies, by hiring specialized companies.

In Canada, the milestone in the environmental licensing process was established by the Canadian Environmental Assessment Act (CEAA), implemented in 1992, with a subsequent update in 2012, being administered by the Canadian Environmental Assessment Agency.

However, on August 26, 2019, it was revoked by the Impact Assessment Act (IAA), administered, in turn, by the Impact Assessment Agency of Canada.

The Canadian Environmental Assessment Agency is a federal institution responsible for administering the 
environmental impact assessment process, with a view to monitoring environmental studies, the responsibility for ensuring public participation, in addition to ensuring that the competent bodies and agencies consider environmental issues in the processes decision-making (Piagentini et al., 2014).

In Chile, it has an EIA system considered to be recent, founded through Law no. 19,300/1994, which was modified through Law no. 20,417/2010, establishing the EIA procedures for projects.

The EIA began to be implemented on a voluntary basis, following instructions from the presidency of the republic. However, it was only in 1996/97 that the process was regulated, introducing the Environmental Impact Statement (DIA) and the Environmental Impact Study (EIA), documents to be presented, depending on the potential impact of the projects.

The aforementioned regulations have positive aspects, such as the creation of a single "window" to simplify the licensing and approval of projects, in addition to a detailed selection criteria for those who must submit to the EIA, but the disadvantage is the tendency that the EIA process starts at an advanced stage of activity planning, due to the detailed engineering projects that are required by the sectoral authority as an approval requirement.

The Environmental Assessment Service (SEA) was created by Law No. 20.417, on January 26, 2010, which amended Law 19.300 / 94 on General Environmental Bases. SEA is the only and exclusive environmental and federal body responsible for the Environmental Impact Assessment System (SEIA).

According to the ChileAtiende portal (2019), any project or activity capable of causing an environmental impact, including its modifications, can only be carried out or modified by prior assessment of its environmental impact, sending, as appropriate, a DIA or an EIA, as described below:

- $\quad$ EIA - if the project generates or has at least one of the effects, characteristics or circumstances established in art. 11 of the Basic Law on the Environment (significant impacts).

- DIA - if the project does not generate or display any of the effects, characteristics or circumstances established in art. 11 of the Basic Law on the Environment.

As an EU nation, Portugal must follow community rules. The Environmental Impact Assessment - EIA process in the European Union was established in 1985 by Directive 85/337 / EEC (European Union, 2017), which was amended three times, in 1997,2003 and 2009.

In addition, not all countries have an environmental license validity period. Chile does not foresee this requirement. In general, in all countries, the sector responsible for preparing the Technical Report has a deadline set for its preparation.

It was sought here to highlight the peculiarities of each country in relation to the specific licensing of hydroelectric plants in order to highlight the main differences between the procedures.

Regarding the jurisdiction and responsibility for regulating the licensing of hydroelectric ventures in the United States, there is a division into federal and non-federal projects, the former being in charge of the US Government Accountability Office (US GAO), a regulatory agency that works for Congress, while the non-federal projects be created by the Federal Regulatory Energy Commission (Federal Energy Regulatory Commission - FERC) (Britto, 2014).

Non-federal projects represent about two thirds of the hydroelectric projects in operation in the USA (1,633 of 2,356 projects) (BRITTO, 2014).

The Office of Energy Projects, FERC's Office of Energy Projects (OEP) is responsible for the management of each licensing process until the vote of the Commissioners and for the supervision of each licensed project thereafter to ensure compliance with the license (FERC, 2012). FERC licenses are issued with a validity of between 30 and 50 years (FERC, 2003). FERC publishes an environmental document, which can be EIS or EA, as required by NEPA, before making its licensing decision (FERC, 2012).

The applicant will synthesize relevant information on the scope of the project, operation (including capacity, generation 
and revenue), and environmental impacts associated with the enterprise in the form of written documents called Exhibits, which will support the preparation of environmental studies by government agencies (FERC, 2012). To prepare these documents, the applicant must compile existing information, and carry out field and other studies to complement the pre-existing information. Such studies are carried out according to the guidelines of a document called a Study Plan, whose initial scope is defined by the corresponding government agency. In the case of hydroelectric projects, this scope is defined by FERC or US GAO.

In the case of Canada will, the licensing process is carried out only if the proposed project is identified in the Project List or the Regulations Designating Physical Activities and after completion of the review of the Initial Project Description by the Agency.

However, if the project has a risk of causing adverse environmental impacts or a relevant public concern occurs, such an environmental assessment can be designated by the Minister for the Environment and Climate Change.

For hydroelectric projects the Regulations Designating Physical Activities specify the construction, operation, decommissioning and abandonment of hydroelectric plants with a generation capacity equal to or greater than $200 \mathrm{MW}$; also inserting the cases of expansion of a hydroelectric plant that results in an increase in the production capacity of $50 \%$ or more, and $200 \mathrm{MW}$ or more.

The stages of construction, operation, deactivation and abandonment of a dam or dike that result in the creation of a reservoir with a surface that exceeds the average annual surface of a body of water by 1,500 hectares or more, or an expansion of a dam or dike that results in an increase in the surface area of a reservoir of more than $35 \%$.

The environmental licensing of new hydroelectric projects has a well-defined basis in each political-administrative, Federal, Provincial and Territorial instance, and, if necessary, an integrated and unique process can also be carried out (Impact Assessment Cooperation Plan Canada- wide Accord on Environmental Harmonization - 1998).

However, a number of specific additional environmental permits are usually also required by different environmental authorities, such as deforestation in a given area.

Such permits can be bulky - they can reach hundreds during the construction phase - depending on the size of the project (WORLD BANK, 2008).

In Brazil, there is a difference between federal projects and projects that are limited only to the states. Hydroelectric projects located or developed in 2 (two) or more States, on indigenous lands, at national borders, or with an installed capacity greater than $300 \mathrm{MW}$ are the responsibility of the federal environmental agency (IBAMA).

Similar to the Terms of Reference, or Brazilian Normative Instructions, which are elaborated by each case, in the case of Chile there are the Guides associated with each Sectorial Environmental License (PAS), and they should serve as guidance and standardization of the criteria, requirements, conditions, background, procedures and technical requirements to obtain the PAS, explaining the procedure step by step, including guiding technical analyses, to describe the area of influence; modeling of groundwater air quality; and biodiversity compensation, to guide the participation of early stages of projects.

As a specific example for hydroelectric and related projects, the Guide for the Evaluation of the Environmental Impact of Hydroelectric Energy Generation Centers generating less than $20 \mathrm{MW}$.

In Portugal, Law No. 58 of December 29, 2005, called the Water Law, whose primary objective is the sustainable management of water and its protection, determines that activities that have a significant environmental impact on bodies of water need a usage title for operation. The competence for licensing water resources is the Portuguese Environment Agency, through the five Hydrographic Region Administration Departments (APA/ARH): Norte, Centro, Tejo, Alentejo and Algarve.

To these institutions, two others comprise the so-called EIA Authorities (Decree-Law No. 151-B / 2013): the group of focal points of the EIA authorities, composed of representatives of all EIA authorities and the EIA Advisory Council (CCAIA), which pronounces on the matters submitted to it for consideration by the national EIA authority or by the member of the 
Government responsible for the area of the environment, in addition to carrying out the generic monitoring of the application of this legal regime, the preparation of recommendations taking into account with a view to improving the effectiveness and efficiency of processes.

EA's performance, foreseen in the Responsible Industry System (SIR), aims to evaluate the conformity of the projects of industrial establishments, with the inherent exemption from consultation with the competent entities.

\subsection{Comparative Analysis of Licensing Processes among countries}

It was found that in all the countries surveyed, EIA is used in all phases of environmental licensing. The EIA is widely used in prior licensing in Brazil, as it the only country whose licensing process has three-phases. It should be noted that in countries like Portugal and Chile there is the possibility of a simple authorization to replace the environmental license. In Brazil, there is no provision for simplified licensing for the installation of hydroelectric plants.

Furthermore, it was established that in all countries surveyed, information regarding each stage of the licensing process is available to the public, as are all data and the information.

In Portugal, there is no explicit provision in the legislation for the environmental compensation for irreversible damage; however, there are measures to compensate for environmental damage provided for in the Environmental Responsibility Directive - DRA. In Chile, there was also no mention of this type of measure. In the remaining countries surveyed, there is an explicit or implicit provision for environmental compensation.

Regarding the responsibility for drafting the EIA or other any other such study, in all countries surveyed it falls upon the entrepreneur, except for the US where the execution of the environmental studies is the responsibility of the presiding federal agency, with the collaboration of the entrepreneur, through the preparation of the necessary studies (Study plans). In Brazil, currently the vast majority of new studies are the responsibility of the Energy Research Company (EPE).

As in Brazil, more than $60 \%$ of the electric energy produced in Canada comes from hydroelectric plants (60\%). Another similarity with Brazil is the presence of indigenous populations that have vast territories with great potential for energy generation; and in most cases, these territories have little occupation. In Brazil, about $13 \%$ of the territory is legally recognized as indigenous areas and in Canada this figure reaches $20 \%$.

Similar to Brazil, which also has most of its remaining hydroelectric potential in the Amazon, 35\% of Canada's existing hydroelectric reservoirs are located in the Taiga biome and $47.6 \%$ in the Boreal Forest. Of the $80 \%$ of the proposed hydroelectric projects and $90 \%$ of the power generated would be located in regions of intact landscapes (Lee et al., 2012).

However, unlike Brazil, in Canada the relationship between the hydroelectric sector and Aboriginal peoples is very integrated, with legal regulations that date back to the 19th century. This relationship is essential for the Canadian electricity sector as the majority of hydroelectric projects are located in areas inhabited by Aborigines.

The Canadian Environmental Assessment Act requires that, in cases of licensing hydroelectric projects, communities are heard and guaranteed public participation in the process, and entrepreneurs are obliged to include the concerns of local people in the process, with this population having the power to veto the enterprise (Fortin, 2001).

In view of this peculiarity, the hydroelectricity industry realized that in order to achieve the development of certain projects, it would be necessary to provide some type of compensation to Aboriginal peoples, such as: effecting the inclusion of these peoples in project decisions, providing training and employment conditions, creating business opportunities and forms of long-term income, guaranteed for a relatively long term (Fortin, 2001). Many companies have opened, within their organization, specific departments for relationships with Aboriginal peoples.

In Brazil, this relationship is still very conflicted and without a well-defined legal framework. For example, Article 231 of the 1988 Federal Constitution, which deals with the use of hydroelectric potential for the production of electricity, has not yet 
been regulated and there is no rule in the Brazilian legal system on the receipt of benefits by indigenous peoples affected by hydroelectric projects.

Regarding the presence of a licensing instrument or other grant, in Portugal there are particular uses in the case of fundraising, constructions, implantation of infrastructures and the License and Concession for public use for fundraising, constructions, implantation of infrastructures.

At the USA there are three types of licenses: Integrated Licensing Process - ILP, Traditional Licensing Process - TLP, and Alternative Licensing Process - ALP.

In Canada: This process takes place only if the proposed project is identified in the Project List or in the Regulations Designating Physical Activities, and after the Agency's review of the Initial Project Description.

There are licenses and authorizations in Chile. For example: aqueducts, reservoirs or traps and siphons that must be subject to the authorization established in article 294 of the Water Code. Dams, drainage, desiccation, dredging or significant alteration of natural bodies or water courses and power generating plants with more than $3 \mathrm{MW}$, among others are subject to environmental licensing.

In the case of Brazil, as recommended in CONAMA Resolution No. 237/1997, the licensing model provided for in both instructions is three-phase, with the issuing of three licenses: LP, LI and LO. It is worth noting that the LO can be valid for a maximum of 10 (ten) years, and must be renewed periodically, so that the environmental licensing process never ends.

Regarding the instruments upon which licensing in Portugal is based, there are The Environmental Impact Study - EIA and the Non-Technical Report - RNT.

In the USA, there is the Environmental Impact Statement (EIS) and the Environmental Assessment (EA). In Canada, the following are the federal legislative base: the Canadian Environmental Assessment Act; the Canadian Environmental Assessment Agency (1992); the Impact Assessment Act; the Impact Assessment Agency of Canada (2012).

In Chile there is a need for an EIA if the project generates or presents at least one of the effects, characteristics or circumstances established in art. 11 of the Basic Law on the Environment - Law 19.300 / 94 (significant impacts).

Regarding the number of stages, in Portugal the licensing is Monophasic with the instrument of the LUA (Unique Environmental Licensing) consists of four stages until the issuance of the license: (i) process instruction; (ii) evaluation of the process; (iii) issuing a technical report; and (iv) inspection.

The situation is diverse in the USA, because the process includes the same installation and operation steps in a single license - single-phase process. In Canada there are 5 stages: Planning (up to 180 days); Impact Statement (up to 36 months); Impact Assessment (Agency: up to 300 days; Review Panel: 600 days); Decision-making (Minister: up to 30 days; Governor: 90 days); post-Decision.

Brazil is the only country to adopt the three-phase Environmental Licensing: Preliminary License - LP, Installation License - LI and Operation License - LO.

As for public access to information on all stages of the process, in Portugal it is through the electronic one-stop shop. In Canada, this information is widely disseminated in the stage entitled Decision-making. In Chile, public consultations are made through an electronic platform called e-SEIA, which allows individuals and legal entities to express their opinions in relation to environmental studies. The SEA portal (http://www.sea.gob.cl/contenido/lista-de-proyectos-en-pac) makes the documents available for public comment, the consultation of which is open to all, but submission of comments is made through registration with personal information.

Public consultations in the USA are carried out by an electronic platform, which has archived all documents since 1989. If the specific record required is not in the eLibrary, one can send a written message to FERC, requesting the documents (HRC, 2012). 
In Brazil, Law No. 10,650 of April 16, 2003 guarantees the transparency of environmental licensing processes, by allowing public access to data and information existing in the bodies and entities that are part of the National Environment System (SISNAMA).

Regarding the existence of public consultation in Portugal, it is present in 4 stages of the process. In the USA, it occurs during all stages of the licensing process. Comments and/or suggestions made by interested parties must be answered.

Public participation in the process is valued in Canada, mainly in consultation with local aboriginal/Indigenous peoples, carried out in the stages of Planning (Planning), Impact Statement, Impact Assessment (for which they carry out public hearings), and the final decision (Post-Decision).

In Chile, Citizen Participation (PAC) in the DIA with environmental charges starts from the last date of notification to interested parties (PAC applicants, titleholder, among others). The maximum period for submitting citizen's observations is 20 working days. The PAC in the evaluation of an EIA includes a rite: after the publication of the extract (summary) of the EIA, a maximum period of 60 days for the submission of citizen's observations is considered.

Consultation processes with indigenous peoples in the Environmental Impact Assessment System (SEIA) are more specific, applying only to projects or activities that are presented in the form of an EIA and that generate significant impacts on indigenous human groups.

In Brazil, the public consultation process takes place in accordance with CONAMA Resolution No. 009/1987 or when determined by the licensing agency with the execution of in-person public hearings when required by interested parties. In Brazil, the public hearing takes place in the prior licensing phase, and other public consultations may occur throughout the process.

With regard to the forecast of environmental compensation in Portugal, there is none. However, there are compensatory remedial measures for environmental damage provided for in the Environmental Responsibility Directive - DRA (APA, 2019).

Otherwise in Chile there are instruments more focused on remedial measures, different from those adopted in Brazil. That is, there is no environmental compensation as there is in Brazil, by article 36 of the SNUC Law.

The case of the USA there is no mention of environmental compensation in NEPA, but there are measures to compensate for environmental damage provided for in other programs, such as the "Wetland Compensation Program".

In Canada, in the step called Post-Decision, the Minister issues the Declaration of the Decision, including detailed reasons related to the determination of the public interest, any enforcement conditions that the Bidder must comply with and the final description of the designated project. Accordingly, conditions must include the implementation of a follow-up program and mitigation measures to eliminate, reduce, control or compensate for the adverse effects of the project, including reimbursement for any damage caused by these effects through replacement, restoration, compensation or any other means. In Brazil, environmental compensation is a measure provided for in art. 36 of Law No. 9,985 / 2000, which obliges the entrepreneur responsible for undertakings of significant environmental impact to financially support (up to $0.5 \%$ of the value of the project) the implementation and maintenance of conservation units. From 2011 to 2019, Federal Environmental Licensing made possible the allocation of almost $\mathrm{R} \$ 2$ billion and the application of $\mathrm{R} \$ 1.2$ billion in Environmental Compensation.

Law 7990, of December 28, 1989, provides for a Financial Compensation for the Use of Water Resources (CFURH), which aims to pay for the use of water resources in the generation of electricity. It is a reimbursement for the flooding of areas by hydroelectric plants (HPP) and a payment for the use of water in the generation of energy. The amount to be paid corresponds to $6.75 \%$ of the total amount of energy produced and charged, with the majority destined to the affected municipalities and states (ANEEL, 2020).

In comparison to the term referring to the entire licensing process, Portugal completes this in 75 days (if there are nonconformities in the process) and 38 days (if the process is properly instructed); the speed of analysis is due to the intervention of the Accreditation Entities - EA in the environmental licensing process. 
Chile for example, the deadline for processing the Declarations is 60 days, and EIAs is 120 days, with the Environmental Impact Assessment Service (SEA) or regional councils, after which, if the respective council does not respond, the project is considered as approved.

For USA, the total term of environmental licensing is undetermined. According to Duthie (2006), the term average in the country of the entire process, from its opening to the issuance of the license, is from 4 to 5 years.

The situation in Canada depends on the type of assessment - Federal, Provincial or jointly reviewed (Joint Review Panel). In addition, the agency responsible for licensing the HPPs depends on their capacity (most of them enter as a Province and others go to the Federal level). It is necessary to emphasize that many HPPs were installed in a period without legislation, and therefore, there are several hydroelectric plants without licensing in the past.

Regarding the licensing processing period, in Brazil this process is indeterminate. However, at the federal level, the following deadlines are foreseen for IBAMA (IN 184/2008): Preparation of the TR - 60 days, Acceptance of the EIA - 30 days, Technical Analysis of the EIA for - 180 days, Analysis of the Basic Environmental Plan - 75 days, LO requirement - 45 days. It should be noted that the counting of deadlines is suspended during the preparation of complementary environmental studies or preparation of clarifications by the entrepreneur.

The responsibility for preparing environmental studies in Portugal, Canada and Chile is the entrepreneur's responsibility. However, in Canada, agencies are responsible for evaluating the process, and recommend whether or not to approve the process. Furthermore, such responsibility for the licensing process can be shared between the political-administrative, Federal, Provincial and Territorial levels, according to the harmonization between the different levels of government of the Canada-Wide Accord on Environmental Harmonization (1998). And, in the case of hydroelectric projects, the responsible entities at the federal level are Fisheries and Oceans Canada (Water Resources), and Transport Canada (Waterways), while the federal Regulatory Body is the Canadian Environmental Assessment Agency - CEAA.

In the USA, it is the responsibility of the competent Federal Agency, with the collaboration of the entrepreneur, through the preparation of the necessary studies (study plans) requested.

At Brazil, the person interested in the project is responsible for contracting environmental studies, together with the professionals who subscribe to the studies, thereby becoming responsible for the information presented. Environmental studies can be prepared by the Energy Research Company - EPE, if it is interested in the project.

As for the legal provision for Strategic Environmental Assessment in Portugal: it is prepared by the Government (Directive 2001/42 / EC of the European Parliament). In Canada, since 2010, the Guidelines for the Implementation of the Directive on the Environmental Assessment of Policy, Plan and Program Proposals describe the overall process and guiding principles of SEA, which were updated in October 2010.

In Chile, Strategic Environmental Evaluation has been in practice since 2010, however only for policies and plans of a general normative nature.

The use of SEA is limited to the Programmatic Environmental Impact Statement (PEIS) in USA, only applied to municipal urban planning programs and plans, with the use of the instrument for the evaluation of regional policies and plans being reduced or non-existent (BRAZIL), 2002; Clark, 2000). However, the NEPA, the law that institutionalized EIA in the USA, requires a prior impact assessment of any federal actions with the potential to generate significant environmental impacts. This term, federal actions, is defined by the Council for Environmental Quality as the projects, programs, regulations, plans or policies carried out by the United States government. That is, it does not require a prior assessment of works or activities only.

Thus, despite the generic definition and the absence of a legal provision that specifically institutionalizes the term SEA, it can be said that the United States has a formal legal obligation to require SEA (Webb and Sigal, 1992; Bass and Herson, 1999; BRASIL, 2002). 
For Hydroelectric Plants in Brazil, SEA has not been formally regulated and is not mandatory, even though it has already been carried out in several cases.

As to the existence of the term of reference (TR) for the preparation of environmental studies, in Portugal there is the Definition of Proposal Scope - PDA, which is presented by the entrepreneur. Regarding terms of reference in the USA, the scope of the term is defined by the competent agency.

At Canada, at the Impact Statement stage, the Agency prepares the draft of the Terms of Reference of the Review Panel. In Chile there is no specific TR per project. There are guides that serve as guidance and standardization of criteria, requirements, conditions, background, procedures and technical requirements for obtaining PAS, explaining step-by-step the procedure for processing these licenses (PAS GUIDE).

The Terms of Reference in Brazil are prepared by IBAMA, based on the information provided by the entrepreneur at FCE and its environmental database, establishing additional guidelines to the general ones contained in Resolution 001/86, which, due to the peculiarities of the enterprise or activity and environmental characteristics of the area, are deemed necessary.

The maximum period for evaluation and licensing in Portugal is 75 days if there is no non-conformity in the process. In the US, this period is indefinite, according to Duthie (2006), the term average in the country for the entire process, from its opening to the issuance of the license, is from 4 to 5 years.

In Canada, the Agency has an Impact Assessment period of up to 300 days, or up to 600 days (if a Review Panel is carried out). The declaration of the decision granting the license / final decision (Post-Decision) must be issued within 30 days after the Impact Report is published in the Registry. However, if the Governor of the Council determines the public interest, the Declaration of the Decision must be issued no later than 90 days after the Impact Assessment Report is published in the Registry. However, it appears that, if feasible, there is a possibility that such terms may undergo modification/extension, if requested by the stakeholder, as well as by the applicant.

For Chile the deadline for processing the Declarations is 60 days, and EIAs is 120 days, with the Environmental Impact Assessment Service (SEA) or regional councils, after which, if the respective council does not respond, the project is considered as approved.

In Portugal, the existence of a Public Hearing with interested parties is a process of consultation at an electronic counter. In Canada, in addition to the participation of the public throughout the process, as mentioned earlier, public hearings are held on the Impact assessment stage (Impact Assessment).

In the USA, in addition to public participation throughout the process, as mentioned earlier, interested parties may request public hearings at the discretion of the regulatory agency. In Chile, there are only public consultations.

Therefore, in Brazil, whenever IBAMA deems necessary; or is requested by a civil entity; the Public Ministry; or by 50 or more citizens, a Public Hearing will be held to present and discuss the project and its respective RIMA.

Regarding the use of fauna collection, in Portugal, USA and Chile there is no reference to the need for this authorization. In Canada, several agencies can enter the process such as Fisheries and Ocean Canada (one of the agencies at the federal level, for example) and request authorization for collection.

While in Brazil it is suitable for any type of fauna management (Collection, Capture, dislocation, and Transport), it is required at the stage of preparing the EIA diagnosis and for monitoring environmental impacts.

In Portugal and Chile there is no reference to the requirement for authorization to remove vegetation, while in Canada, there are a number of specific additional environmental permits that are usually also required by different environmental authorities, such as deforestation in a given area.

Compared to Brazil, the agency responsible for environmental licensing is responsible for issuing authorization to remove vegetation. The resumed framework of country comparisons is presented in Table 1. 
Table 1. Compared Aspects of the Environmental Licensing of Hydroelectric Plants of Each Studied Country.

\begin{tabular}{|c|c|c|c|c|c|}
\hline \multirow{2}{*}{ QUESTION } & \multicolumn{5}{|c|}{ COUNTRIES STUDIED } \\
\hline & PORTUGAL & USA & CANADA & CHILE & BRAZIL \\
\hline $\begin{array}{l}\text { Licensing or other } \\
\text { grant instrument }\end{array}$ & YES & YES & YES & YES & YES \\
\hline Licensing instrument & EIA & EIA & EIA & EIA & EIA \\
\hline Number of steps & 1 & 1 & 1 & 1 & 3 \\
\hline $\begin{array}{c}\text { Public access to } \\
\text { information on all } \\
\text { stages of the process }\end{array}$ & YES & YES & YES & YES & YES \\
\hline $\begin{array}{l}\text { Existence of public } \\
\text { consultation }\end{array}$ & YES & YES & YES & YES & YES \\
\hline $\begin{array}{l}\text { Environmental } \\
\text { Compensation } \\
\text { Forecast }\end{array}$ & NO & N/A & YES & NO & YES \\
\hline Full license term & $\begin{array}{c}75 \text { days or } 38 \\
\text { days }\end{array}$ & - & $\begin{array}{l}\text { Planning (up to } 180 \text { days) } \\
\text { Impact Statement (up to } 36 \\
\text { months) Impact Assessment } \\
\text { (Agency: up to } 300 \text { days; } \\
\text { Review Panel: } 600 \text { days) } \\
\text { Decision-making (Minister: up } \\
\text { to } 30 \text { days; Governor: } 90 \text { days) } \\
\text { Post-Decision }\end{array}$ & $\begin{array}{l}\text { Between } 60 \\
\text { to } 120 \text { days }\end{array}$ & Indeterminate \\
\hline $\begin{array}{l}\text { Responsibility for } \\
\text { preparing the study }\end{array}$ & Entrepreneur & Authority & Entrepreneur & $\begin{array}{c}\text { Entrepreneu } \\
\mathrm{r}\end{array}$ & $\begin{array}{l}\text { Entrepreneur or } \\
\text { Energy Research } \\
\text { Company }\end{array}$ \\
\hline AAE legal forecast & YES & NO & YES & YES & NO \\
\hline $\begin{array}{l}\text { Existence of a term } \\
\text { of reference (TR) for } \\
\text { the preparation of } \\
\text { environmental studies }\end{array}$ & YES & YES & YES & NO & YES \\
\hline $\begin{array}{l}\text { Maximum term for } \\
\text { evaluation and } \\
\text { granting of license }\end{array}$ & 75 days & - & $\begin{array}{l}\text { The Impact Assessment has a } \\
\text { period of up to } 300 \text { days by the } \\
\text { Agency, or up to } 600 \text { days (if a } \\
\text { Review Panel is carried out). }\end{array}$ & $\begin{array}{l}60 \text { to } 120 \\
\text { days }\end{array}$ & $\begin{array}{l}\text { Varies according } \\
\text { to the licensing } \\
\text { agency }\end{array}$ \\
\hline $\begin{array}{l}\text { Existence of public } \\
\text { hearing with } \\
\text { interested parties }\end{array}$ & NO & YES & YES & NO & YES \\
\hline $\begin{array}{l}\text { Authorization for } \\
\text { fauna collection }\end{array}$ & N/A & N/A & N/A & NO & YES \\
\hline $\begin{array}{l}\text { Requirement of prior } \\
\text { authorization to } \\
\text { remove vegetation }\end{array}$ & N/A & N/A & YES & NO & YES \\
\hline
\end{tabular}

N/A: Not applicable. Source: Authors.

Brazil is the only country surveyed that has a three-phase licensing system, however it cannot be said that this is detrimental to licensing. Due to the fact that it is a country with a continental and mega diverse and great territorial extension, there is a need for several steps to analyze more carefully the environmental impact that hydroelectric projects cause on the environment and on the way of life as people.

Canada and Brazil have in their environmental legal system an important instrument for environmental compensation, as well as the availability of important financial resources to compensate and as impacted regions and as people who have their 
way of life modified by the construction and operation of the UHEs.

Canada is seen as a reference in the world for the good relationship between hydroelectric projects and indigenous communities, although the country's indigenous communities have greater integration and contact with non-Indians, Brazil should follow Canada's example to improve the relationship with indigenous peoples, to ensure that it is more transparent and harmonious.

All countries have a good degree of transparency with information on projects and licensing. In Brazil, it appears that the system should be more transparent in the stages of making the project feasible, before the EIA. At this stage, it is common for locals to be surprised by information about a possible HPP in their territory, before being officially communicated by the government or company responsible for the work.

A major bottleneck in Brazil, due to the complexity of the projects, and sometimes due to the lack of technical capacity of the licensing agencies, is the long time elapsed from the beginning of the analysis of the project, until the final license. Countries like Canada, Portugal and Chile estimate deadlines for the end of the analysis of the process, Portugal and Chile have deadlines of up to 120 days.

Brazil, through investments in its environmental licensing agencies, could set maximum deadlines for analyzing the HPP processes in its environmental planning, so that these processes would not take years to have their final license granted or denied.

Brazil is the only one of the countries analyzed that has fauna collection authorization, which positively differs from the country, these collections are very important because the flooding of areas to the reservoirs generates fauna loss that can be relocated to other locations. Authorization to remove vegetation, only Canada and Brazil have. Both countries have large areas of forest and this instrument helps to control and compensate the vegetation removed during construction and reservoir formation.

\section{Final Considerations}

In Brazil, there is no homogeneity and standardization regarding the framing of enterprises and Environmental Licensing criteria, as this is defined at the state level (Federated Brazil). Currently, PL 3.739 of 2004, known as the General Environmental Licensing Law, is still in process, which aims precisely at this greater standardization and simplification of licensing in the country.

Of the countries surveyed, Brazil is the only one that adopts the three-phase licensing model and the periodic need to renew licenses. This model generates a large number of license requirements, which overburdens environmental agencies and demands greater effort and investment from interested companies. It is worth considering, however, that this particularity is largely justified by the country's striking characteristics: its extraordinary biodiversity, the existence of traditional populations and the search for the use of rivers located in sensitive areas, especially in the Amazon region.

Examples of good international practice are: transparent processes and effective means of information and social participation from the beginning and in all its phases, and not just access to technical documents; two-way participation (dialogue between the entrepreneur and the public); conflict mediation before decision making.

It was found that although all countries surveyed adopt the EIA as an instrument for the environmental management of projects, the environmental licensing procedure is quite heterogeneous. There is no uniformity in relation to the planned steps, necessary documents, deadlines, environmental compensation, responsibility for preparing studies and making decisions regarding the issuance of licenses.

In common, the provision of public participation and public access to the documents of the process stands out. There are good participation and transparency practices already incorporated into the procedures of all the countries surveyed. It can 
be said that there does not seem to be a perfect licensing model or EIA for projects.

Comparative international experiences are important for possible adjustments in the Brazilian licensing process, however, one must not confuse the bureaucracy of the process with excessive simplification. Models that are efficient in other countries, when imported, must take into account the peculiar Brazilian socio-environmental reality with all its nuances.

\section{References}

ANEEL. (2020). Financial Compensation (CFURH) - Legal Aspects. Agência Nacional de Energia Elétrica. http://www.aneel.gov.br/cfurh-aspectos-legais.

APA. (2019). Avaliação de impacte ambiental do aeroporto do Montijo e respetivas acessibilidades: Proposta de Declaração de Impacte Ambiental Favorável Condicionada. Agência Portuguesa do Ambiente (APA). https://www.tsf.pt/portugal/sociedade/agencia-portuguesa-do-ambiente-aprova-com-condicoesaeroporto-do-montijo-11464718.html

Bass, R. \& Herson, A. (1996). Strategic environmental assessments in the US: policy and practice under the National Policy Act and the Californian Environmental Policy Act. Paper presented in IAIA'96 16th Annual Meeting, Estoril

Ben. (2019). National Energy Balance. MME. Ministry of Mines and Energy. Base Year 2018. Brazil, 2019.

Bermann, C. Hydroelectricity impasses and controversies. Advanced Studies, São Paulo, 21 (59), 2007. P. 139-153.

BRAZIL. (2002). MMA - Ministry of the Environment. Strategic Environmental Assessment. Brasília: MMA; SQA.

Britto, F. (2014). Critical analysis of the environmental licensing of HPPs in the Brazilian Amazon. Doctoral thesis. Graduate Program in Civil Engineering. COPPE / UFRJ. Rio de Janeiro.

Chile Atiende Portal. Environmental Impact Study (EIA) and Environmental Impact Statement (DIA). https://www.chileatiende.gob.cl/fichas/2638-estudio-deimpacto-ambiental-eia-y-declaracion-de-impacto-ambiental-dia

Damazio, J., Medeiros, A., \& Abreu, J. et al. (2017). Data Analysis of Campaigns to measure emissions and removals of greenhouse gases in hydroelectric plants in Brazil. ANEEL research and development magazine, 98-101.

Drummont, E. \& Nascimento, J. Amazônia: Economic dynamism and environmental conservation. 1 st ed. 336p. Publisher Garamond. Rio de Janeiro, 2003.

FERC. federal energy regulatory commission. Code of Federal Regulations (CFR). 2012. http://www.ferc.gov/help/faqs/cfr.asp

FERC. federal energy regulatory commission. Hydroelectric Licensing under the Federal Power Act. 2003. http://www.ferc.gov/whats-new/commmeet/072303/H-1.pdf

FORTIN, P. (2001). The hydro industry and the Aboriginal people of Canada: Paving the way for new relationships. Hydropower \& Dams i. 3, p. 47-50.

Gonzalez, D., Kilinc, A., \& Weidmann, N. (2011). Renewable energy development hydropower in Norway. In Hydropower Norway Seminar Paper.

HRC. Hydropower Reform Coalition Citizen guide for effective participation in hydropower licensing. [S1], 2015.

IEA HIDROPOWER. Survey of existing guidelines, legislative framework and standard procedures for EIA of hydropower projects. IEA Technical Report. 2000.https://www.ieahydro.org/media/51693b42/Survey\%20of\%20xisting\%20guidelines,\%20legislative\%20framework\%20and\%20standard\%20procedures $\% 20$ for\%20EIA\%20of\%20hydropower\%20projects.pdf

IEA. (2012). International Energy Agency. Technology Roadmap Hydropower. 68p. Paris.

IEA. (2020). International Energy Agency. Global Energy \& $\quad$ CO2 Status Report. https://webstore.iea.org/download/direct/2461?filename=global_energy_and_co2_status_report_2018.pdf

IPCC. (2014): Climate Change 2014: Synthesis Report. Contribution of Working Groups I, II and III to the Fifth Assessment Report of the Intergovernmental Panel on Climate Change. [Core Writing Team, R.K. Pachauri and L.A. Meyer (eds.)]. IPCC, Geneva, Switzerland, 151 pp. https://www.ipcc.ch/report/ar5/syr/

Kumar M. (2020). Social, Economic, and Environmental Impacts of Renewable Energy Resources. In K. E. Okedu, A. Tahour, \& A. G. Aissaou (Eds.), Wind Solar Hybrid Renewable Energy System. IntechOpen. https://doi.org/10.5772/intechopen.89494

Lee, Peter G, Hanneman, Matt, \& Cheng, Ryan. (2012). Hydropower developments in Canada: number, size and jurisdictional and ecological distribution. Global Forest Watch Canada, 64 p.

Mercure, J. F., Salas, P., Vercoulen, P., Semieniuk, G., Lam, A., Pollitt, H., \& Vinuales, J. E. (2021). Reframing incentives for climate policy action. Nature Energy, 6(12), 1133-1143.

MMA. (2020). Federal Environmental Licensing Procedures Guide. Reference document. Brasília, 2002. https://www.mma.gov.br/estruturas/sqa_pnla/_arquivos/Procedimentos.pdf

Natural resources canada. (2019). Electricity facts. https://www.nrcan.gc.ca/electricity-facts/20068\#L3 
Research, Society and Development, v. 11, n. 3, e17711326408, 2022

(CC BY 4.0) | ISSN 2525-3409 | DOI: http://dx.doi.org/10.33448/rsd-v11i3.26408

PIAGENTINI, P; Favareto, The Institutions for environmental regulation: the environmental licensing process in four hydroelectric producing countries. Development and Environment, v. 30, p. 31-43, Jul. 2014.

Rosenberg, D. M.., McCully, P., \& Pringle, C. M. (2000). Efeitos ambientais de alterações hidrológicas em escala global: introdução. BioScience , 50 (9), 746751.

Santos, M. \& Rosa, L. (2013). Hydroelectric Power Plants. In: New and renewable energy sources. p.179-192. SANTOS, M (Orgs). 216p. Publisher LTC. Rio de Janeiro.

Santos, M., Rosa, L., Matvienko, B., Santos, E., \& Rocha, C. et al. (2008). Emissions of greenhouse gases by hydroelectric reservoirs. Oecologia Brasiliensis, 12 (1): 141-154.

Silva Júnior, O; Santos, M., \& Szlafsztein, C. et al. (2018). Protected areas as strategies for preserving vegetation cover in the vicinity of hydroelectric projects in the Brazilian Amazon. Energy Sustainability and Society 8: 33. https://doi.org/10.1186/s13705-018-0172-1

Steeves, B. B., \& Ouriques, H. R. (2016). Energy security: China and the United States and the divergence in renewable energy. Contexto Internacional, 38, 643-662.

US EIA. (2012). US Energy Information Administration Electricity in The US. https://www.eia.gov/energyexplained/electricity/electri city-in-the-us.php Von Sperling, E. (2012). Hydropower in Brazil: overview of positive and negative environmental aspects. Energy Procedia, $18,110-118$.

Webb, J. W., \& Sigal, L. L. (1992). Strategic environmental assessment in the United States. Project Appraisal, 7(3), $137-142$.

Word Bank. (2008). Licenciamento Ambiental de Empreendimentos Hidrelétricos no Brasil: Uma Contribuição para o Debate. (Em Três Volumes). Volume I: Relatório Síntese. Relatório No 40995-BR. Escritório do Banco Mundial no Brasil, Estudo Econômico e Setorial, Região da América Latina e Caribe. 